\title{
Prejudice Between Educators
}

\author{
Marija Šlutej \\ International School for Social and Business Studies, Slovenia \\ mari.lah05@gmail.com
}

Purpose: We want to explore the presence of prejudices between teachers and kindergarten teachers based on a program of education (regular, special).

Study design/methodology/approach: A quantitative study was conducted in which a survey method was used. 167 educators were involved. It was conducted on the $1 \mathrm{ka}$ web portal.

Findings: Research has highlighted that family, kindergarten, school, media, and children's literature influence the origin of prejudice in children. The environments and relationships in which children grow up are therefore crucial for the development of prejudice.

Originality/value: It is crucial that educators raise awareness of prejudices, think about them, name them and try to alleviate them. The entire education system must be included through additional training, practical experience, discussions, articles, professional literature, etc. Only this can provide adequate support and changes in this critical area.

Keywords: prejudice, educators, kindergarten, school
Management,

ma ke Knowledge and Learning

le a r n International Conference 2021

Technology, Innovation and Industrial Management

Economy for a New Normal: Digitalisation and Human Relations in Business and Education 20-21 May 2021 Online Conference

\section{Introduction}

Prejudices are present in all areas of our lives. They form in us from an early age. Their form is influenced by various factors, environments, people, experiences. Adults are role models for children, so it is essential to be aware of the role of educators and teachers. In our work, educators encounter various vulnerable groups to whom we have formed opinions and views. The article is based on my master's thesis. We wanted to explore the presence of prejudices between teachers and kindergarten teachers in elementary school and kindergarten in Slovenia. In the theoretical part, we presented information on prejudices, described the role of the school/kindergarten and educators in this field. In the empirical part, we researched professionals' attitudes towards five vulnerable groups - immigrants, Roma, races, special needs, and the socio-economically endangered. We checked their beliefs and ways of working at the kindergarten and school levels. We have found out that there are prejudices among educators. Kindergarten employees and employed in regular education programs have more prejudices.

On the other hand, we have found that professionals feel competent to teach topics in the area of prejudice. They also recognise them and respond to them accordingly. With the master's thesis results, we want to raise awareness of the presence of prejudice among professionals. It is also essential to shed light on the role of school and kindergarten, which must represent a safe and stimulating environment.

\section{Theoretical points}

We encounter prejudices every day and work with them in all areas of life. They arise in different ways and are in each of us. It is up to us whether we are aware of them, acknowledge them, want to make them aware, change them, mitigate them. The everyday notion expresses the belief that prejudices are unjustified and fact-based judgments. Their importance lies in value assessments. They can be positive or negative. We talk about the positive when we value and glorify certain groups, professions, phenomena, institutions; however, on the negative side, when superiority, inferiority, and fear are expressed (Ule, 2004). 
The diversity of children is reflected in gender, socio-economic status, health status, cultural background, religion, nationality, etc. In schools, diversity provides a rich structure of classes; in which children with special needs, the gifted, minorities, and others are also present (Grah, Kruh, Vovk - Ornik and Rogič Ožek, 2019). We need to be aware that many prejudices stem from early childhood. From adults, children make judgments about the outside world. Research has pointed out that the origin of prejudices in children is influenced by family, kindergarten, school, media, children's literature (Ule, 2004). For schools not to become a hotbed of conflict, we need to be able to deal with prejudice. It is necessary to develop tolerance, which means acceptance, and to present difference as something interesting (Palomares, 2001).

The conditions for the emergence of prejudices can be divided into broader and individual ones. The broader macro-social conditions include economic-political and cultural-normative conditions. First, it is about the influence of social structures (Ule, 2004). Allport (1979) draws attention to the accelerated development of prejudices due to the escalation of the differentiation of society. Cultural-normative influences are strongest when they are justified and reinforced by norms and cultural patterns of behaviour. Second, social psychology deals with microsocial conditions and distinguishes between two primary sources of prejudice: socialisation in the first years of life and crises in adult life. In childhood, we create categorisations and evaluations that are related to emotions. This is the basis for the emergence and existence of prejudices. Researchers have found that prejudices increase the intensity until late adolescence, and findings vary with space and time (Ule, 2004).

No child is born with prejudices, but they are passed on to him through society. Children are most intensely influenced by the opinions of important others in their environment - parents, grandparents, educators, etc. They observe the behaviour of others to whom they represent a role model. Through rewards, they reinforce the child's behaviour according to their beliefs they reward behaviour that they find acceptable. Psychoanalysts talk about a specific educational style that contributes to the emergence of prejudice and discrimination. Strict punitive methods, lack of sympathy, demands to suppress instincts, suppression of autonomy, excessive emphasis on obedience is typical. The result is the acquisition of a hierarchical view of society, dividing the privileged and deprived (https://zofijini.net/predsodki-stereotipidiskriminacija-1-del/).

The most primary prejudices are those relating to gender and nationality. At the age of three, children begin to build stereotypical categorisations regarding gender and ethnicity. This peaks at 5-7 years and later declines (Brown, 2001). People are not born with prejudices, but we learn them directly and indirectly. Children are most receptive to adopting beliefs, attitudes, and mirroring behavioural patterns. As a result, prejudices firmly ingrained in culture are easily passed on (Palomares, 2001).

The school is supposed to represent real life in the community. Children of different cultures meet in them, so the task of schools is to acquaint children with cultural differences and values in the modern world. It is essential to emphasise the duty to equal rights of everyone. We need to train young people for the challenges of the modern world, following the development of society, change with it and provide knowledge to reflect it (Kroflič, 2002).

Personal contact with values is of utmost importance. The student must learn values and acquire them through relationships in the school community, experience them personally (Kroflič, 2004). The school needs to raise awareness of human rights. The teacher must be an example to show students how to respect rights and responsibilities. Ule (2004) writes about the strategy of joint schooling of children. The central belief is that joint schooling of children from different ethnic or racial groups reduces prejudice. Children are in touch, help each other, cooperate, and thus understand individual perception and evaluation of others. Prevention of prejudice must 
begin in concrete and everyday situations. It is pointless to explain stories to children about people friendly to other nationalities because they do not yet cognitively link the teachings of stories with categorisations. It is vital to deal with children's everyday world, with parents and peers (Ule, 2004).

Low expectations of teachers affect students' results and goals. With their expectations, teachers can significantly impact students, who consequently confirm stereotypes with their behaviour and outcomes. For this reason, teachers must support students and believe in their potential. With such an approach, they provide a safe and stimulating learning environment where students can demonstrate their strengths and meet expectations (PREDIS, 2013). In addition, teachers and educators need to be able to adapt to a changing society. Most, especially the elderly, grew up in a monocultural environment, making it impossible to contact other cultures. As a result, they may have multiple stereotypes, conflicts, and exclusions toward those different from them.

Today, more attention is being paid to the formation of values in education, mainly due to the lack of values. The purpose is to discover the best in the child and enable him to develop all aspects of his personality. With its structure, the school significantly co-shapes the values of children (Gogala, 1966). The democratic culture of the school influences the formation of ethical values, where tolerance and respect are a condition for democracy. Imposing values often leads to denial and rejection, so we need to give children the daily practice of tolerance to help them consider others. Personal contact with values is therefore of the utmost importance. The student must learn the values and acquire them through relationships in the school community, experience them personally. Education must not conflict with school life (Kroflič, 2004). Problems arise when parents feel that values at school do not match domestic ones. In public schools and kindergartens, it is necessary to follow and respect the values expected in the country and not exclude anyone, which is not easy in practice (Krek et al., 2011). It is the school that needs to raise awareness of human rights. The teacher must be an example to show students how to respect rights and responsibilities.

Schools can do a lot to improve relationships, reduce tensions and conflicts between students. It is encouraging for the school to introduce norms and rules that support differences and provide sanctions for any harassment. A school with a healthy attitude towards differences has a good school climate; students are not afraid of differences and do not hide from them. There are many procedures for breaking down stereotypes and prejudices and consequently preventing discrimination. Students should be exposed to differences. Self-presentation and getting to know others should take place during the conversation. Research shows that students are more tolerant of the ethnic groups they know. Students who work in a group and strive to achieve common goals develop positive attitudes toward each other. They need to have as many different positive experiences with peers as possible (Palomares, 2001). Bešter (2007) draws attention to the importance of the school system as a medium of socialisation, contribution to unity, and support in the formation of ethnic identity. They must provide an understanding of diversity.

Košir (2013) provides guidelines for improving the relationship between students and teachers: interest in life outside of school, taking time before or after school, following suggestions, consistently using behavioural management strategies (fairness, clear boundaries, feedback, respect). Relationships must be based on trust, autonomy, empathy, self-confidence, and initiative. Teachers mention the most critical competencies, knowledge, and skills for work, such as ingenuity, empathy, openness, acceptance of difference, tolerance, attitude without prejudices, respect, etc. (Osmanović, 2019). 
Bešter (2007) points out that it is necessary to check school curricula and include the treatment of different cultures and communities. In addition, it is needed to provide teachers with additional training and education and update educational programs for educators. The Institute on Ethnic Issues survey found that immigrants experience unequal treatment at school based on ethnicity. However, they also experience discrimination by teachers, which manifests itself as disrespect, shame, insults, and exposure.

Bluestein (2001) emphasises the importance of the involvement of all factors in the environment. He describes an emotionally safe school as a school where students have a sense of belonging, acceptance, value, respect, make mistakes, experience success, and accept their qualities. Clear expectations, consistency, a sense of security, freedom to decide on the way to learn, security against prejudice and discrimination, freedom to express emotions and opinions are essential. He also mentions the factors that educators need to pay attention to, as they pose a threat to experiencing emotional security. He cites overly demanding tasks, vague instructions, lack of help, support, materials, and time. A major problem today is ignorance of language and discrimination based on race and religion. The role of educators, who must take care of the well-being of all children, is important here.

A safe and stimulating learning environment is vital for children with special needs. For the most part, we are tolerant of those whose shortcomings are visible outwardly. However, children with special needs mostly do not get enough understanding. The problem is the belief that good is the only thing that is in the majority. Ignorance can provoke in people an unexplained fear of the unknown and lead to the formation of stereotypes. We need to teach children from an early age to accept and respect differences. We need to answer their questions to make them easier to understand. We adults have set an example for them as they take our patterns of behaviour. The topic can be brought closer to them with various activities: writing with a non-dominant hand, communicating with pantomime, guiding the blind, etc. We must have zero tolerance for violence. Only in this way will we provide everyone with a safe and stimulating environment (Kesič Dimic, 2015).

Education (teaching, upbringing, and learning) is primarily a culturally conditioned process that always takes place in a particular social context and space. For this reason, intercultural education can be understood as a topical response to global social changes related to the linguistic and cultural diversity of the ever-changing modern society. Today, intercultural education and intercultural pedagogy are perceived as the most appropriate response to the phenomenon of globalisation and the growing acceptance of different linguistic, religious, cultural patterns of behaviour and ways of thinking (Klemenčič and Štremfel, 2011). Furthermore, Interculturalism encourages developing a more equal relationship of cultures, a view of the difference from the equal, leadership that enables real success and the development of community values (Ermenc, 2006).

Schools need to adapt to the effects of globalisation and provide quality and equitable education. They play a leading role in the inclusion of society, as they are the most critical opportunity for immigrants to get to know and achieve cultural respect. The school must help them to integrate more easily into education and thus enable them to find employment and competitiveness in the future. The school has a vital role in promoting children's intercultural attitudes, values, skills, and knowledge. Due to societal changes, many aspects need to be reshaped: goals, content, teaching methods, assessment, organisation, demand for teaching materials, rights and responsibilities, additional teacher education, and the relationship between the school, the local community, and parents. Interculturality highlights the importance of the contribution of different cultures to the educational environment and the enrichment of this environment, thus raising students' awareness of their origins and identity. We need to help 
students accept the differences and integrate them into our society. Interculturalism strengthens the development of common school culture, as it is based on knowing and respecting the different ways of life present in school. It includes recognising others and cooperating with individuals from different cultural backgrounds (including special needs and lifestyles) (Klemenčič and Štremfel, 2011).

Acquiring intercultural competence requires ongoing training to be aware of one's views and expectations. We need to be aware of co-responsibility for successful integration. These are long-term processes that are invaluable to students. Project participation and exchange of experiences lead to good practices. With their knowledge and activities, teachers and educators must promote the development of intercultural education (Vižintin, 2017). Teachers and educators need to support the growth of students regardless of their background. It is necessary to create an atmosphere that benefits all cultures. In this way, students develop acceptance, empathy, and support (Trunk Širca and Novak Trunk, 2017).

In education, Slovenia is facing the challenges of socialisation, discrimination, and the promotion of democracy in Europe. Education is the foundation for intercultural communication and respect for diversity, as knowledge is key to creating a just and solidary global society. Curricula must be flexible and include intercultural topics (Židan, 2007). MIZŠ (2017) emphasises that knowledge is the most powerful weapon against stereotypes. With it, we promote multiculturalism in education and train future teachers and educators. Knowledge encourages critical thinking and antitheses prejudice. The role of the whole environment of schools and kindergartens is crucial. The inclusion of diverse children strengthens the participation of children, professionals, and parents. It prevents exclusion and provides equal opportunities for all, as it respects diversity. One of the fundamental principles is equal opportunities, which says that we must treat all students equally and prescribe equal rights and obligations for all. We must improve the situation of all children in upbringing and education, regardless of their circumstances. If we want to achieve this, the roles of professionals must be clearly defined, and we must offer them help, establish teams, support them with new knowledge, and take into account their strengths and weaknesses (Grah et al., 2019).

Research in America has shown that prejudices escalate over the years and become more complex. They also showed that preschool children are already aware of racial differences. During maturation, children complement prejudices with beliefs that are intertwined and reinforced. Problems arise when they are associated with negative emotions and negative evaluation (Ule, 2004). In adolescence, there is a strong desire to belong and associate with peers, which facilitates identification and increases the feeling of connection and belonging. This has a significant impact on self-image development (Palomares, 2001).

In some European countries, Roma children have often been referred to schools with adapted curricula. An ERRC survey conducted in 1999 in the Czech Republic found that more than half of Roma children attended a school with an adjusted program. However, in most countries, there are no relevant statistics to show an accurate picture of discrimination. Some countries even block efforts to obtain such information (Peace Institute, 2003). In America, a survey of ethnic stereotypes was conducted that showed an important link between the preferences of individual nations and the traits given to those nations by the subjects. They rated their nationbest and Turks and blacks the worst (Ule, 2004). Kuhar (2008) writes about the situation in Europe. We can still find many anti-semitisms, hatred of the Roma, and more and more Islamophobia. One of the biggest challenges in Europe and Slovenia is the attitude towards migrants, asylum seekers, and refugees. Europe needs migration to grow economically and maintain living standards. 
We conducted a quantitative study in which we used a survey method. We used the survey method because the topic is very sensitive. We think we got answers that are more honest through anonymity. The pattern is dedicated. 167 educators were involved. The survey questionnaire covered sociodemographic questions and statements assessed on a Likert scale by teachers and kindergarten teachers. We formulated the claims for the personal level, the level of working with children, and the level of the organisation as a whole. We surveyed the $1 \mathrm{ka}$ web portal. We analysed the data using the SPSS program. We included two open-ended questions on the experience of educators with prejudices in the workplace. We analysed the data collected from the open-ended questions with qualitative content analysis.

The purpose of the master's thesis was to investigate the presence of prejudices between teachers and educators in selected primary schools and kindergartens in Slovenia. We were interested in being aware of and experiencing their prejudices and confronting them. We also wanted to research if they are further educated in this area. With these findings, we would like to contribute to additional training programs and draw attention to the prevalence of prejudice in education.

We set the following goals:

- Research theory and research in the field and emphasis in the field of education.

- Explore attitudes and awareness of prejudice.

- Investigate the link between prejudice and the work of professionals.

- Investigate examples from practice and behaviour in direct situations related to prejudice.

- Give conclusions and suggestions for training professionals.

In the empirical part, based on the theoretical starting points, purpose, and goals of the research, we set hypotheses:

- H1: There are prejudices among professionals.

- H2: Professionals working in kindergartens and schools with a customised program have fewer prejudices than those working in a regular education program.

- H3: Professionals recognise prejudices and respond to them appropriately.

- H4: Professionals do not feel competent in the field of prejudice.

- H5: Older professionals have more prejudices than younger ones.

\section{The questionnaire}

We designed our own questionnaire, in which we covered various aspects of the work of professionals who are affected by prejudice. The survey questionnaire covered sociodemographic questions and claims that were rated by experts on a Likert scale. The claims covered various areas - personal, work, organisational. In addition, we included two open-ended questions about the concrete experiences of professionals with prejudices in the workplace in the survey.

We collected data for about a month (March-April 2020). 167 professionals participated in the survey, of which 135 solved the survey altogether. Therefore, they did not receive an award for their participation, and the anonymity of the institution and employees was ensured. 
The questionnaire started with questions about employment, education program, age, and residence. Table 1 shows where survey participants work. 114 (68.3\%) respondents work in kindergarten and 53 (31.7\%) at school.

Table 1: Employment

\begin{tabular}{|l|l|l|l|l|}
\hline & & Frequency & Percentage & Applicable percentage \\
\hline \multirow{3}{*}{ Valid } & Kindergarten & 114 & 67,5 & 68,3 \\
\cline { 2 - 5 } & School & 53 & 31,4 & 31,7 \\
\cline { 2 - 5 } & Together & 167 & 98,8 & 100,0 \\
\hline \multirow{2}{*}{ Missing } & System & 2 & 1,2 & \\
\hline \multirow{2}{*}{ Together } & & 169 & 100,0 & \\
\hline
\end{tabular}

Figure 1 shows the employment of research participants according to the education program. $10.18 \%$ of respondents implement an adapted education program, and $89.82 \%$ a regular education program. From these data, we can understand that the participants in the research are primarily employed in kindergarten, namely in the regular education program.

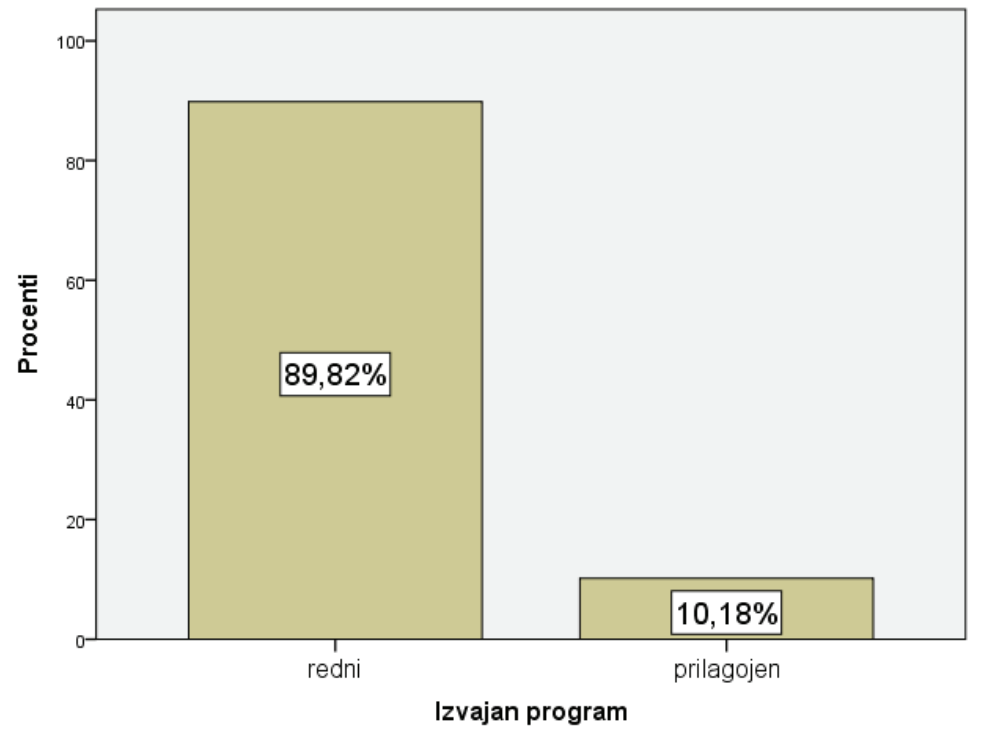

Figure 1: Program

This was followed by claims covering various vulnerable groups: immigrants, Roma, racial diversity, children with special needs, and the socio-economically disadvantaged. Examples of claims: "Immigrants should be able to learn their mother tongue. Roma children affect the safety of other children. Children of all races must be treated equally. A child with special needs hinders the work of other children." Professionals rated them according to the Likert scale. General, personal and organisational statements were also made. Examples: "We actively cooperate with parents of children with special needs. We are planning activities on the topic of raising children's awareness. The environment is safe and encouraging for all children." When using the Likert scale, I offered answers in five stages: I disagree entirely, I disagree, I cannot define myself, I agree, and I agree completely. 
Table 2: Attitudes towards children with special needs

\begin{tabular}{|l|l|l|l|l|l|}
\hline & $\begin{array}{l}\text { Strongly } \\
\text { disagree }\end{array}$ & Disagree & $\begin{array}{l}\text { Cannot } \\
\text { define }\end{array}$ & Agree & $\begin{array}{l}\text { Strongly } \\
\text { agree }\end{array}$ \\
\hline $\begin{array}{l}\text { Children with special } \\
\text { needs should be } \\
\text { educated in schools } \\
\text { with an adapted } \\
\text { program. }\end{array}$ & $7,5 \%$ & $17,8 \%$ & $21,9 \%$ & $38,4 \%$ & $14,4 \%$ \\
$\begin{array}{l}\text { A child with special } \\
\text { needs hinders the } \\
\text { work of other } \\
\text { children. }\end{array}$ & $10,3 \%$ & $34,9 \%$ & $22,6 \%$ & $28,8 \%$ & $3,4 \%$ \\
\hline $\begin{array}{l}\text { A child with special } \\
\text { needs has a positive } \\
\text { effect on developing } \\
\text { social skills in others } \\
\text { in } \\
\text { classroom/playroom. }\end{array}$ & $2,1 \%$ & $7,5 \%$ & $19,2 \%$ & $53,4 \%$ & $17,8 \%$ \\
\hline
\end{tabular}

Table 3: Ways of working in kindergarten/school

\begin{tabular}{|l|c|c|c|c|c|}
\hline & $\begin{array}{l}\text { Strongly } \\
\text { disagree }\end{array}$ & Disagree & $\begin{array}{l}\text { Cannot } \\
\text { define }\end{array}$ & Agree & $\begin{array}{l}\text { Strongly } \\
\text { agree }\end{array}$ \\
\hline $\begin{array}{l}\text { We are planning } \\
\text { activities on the topic } \\
\text { of raising awareness } \\
\text { of prejudices. }\end{array}$ & $0,0 \%$ & $6,3 \%$ & $13,9 \%$ & $55,6 \%$ & $24,3 \%$ \\
\hline $\begin{array}{l}\text { We provide feedback } \\
\text { and tips for working } \\
\text { with different } \\
\text { groups. }\end{array}$ & $0,7 \%$ & $4,9 \%$ & $6,9 \%$ & $57,6 \%$ & $29,9 \%$ \\
\hline $\begin{array}{l}\text { We strive to create a } \\
\text { safe and stimulating } \\
\text { learning environment } \\
\text { for all children. }\end{array}$ & $0,7 \%$ & $0,7 \%$ & $0,7 \%$ & $30,6 \%$ & $67,4 \%$ \\
\hline $\begin{array}{l}\text { The environment is } \\
\text { safe and stimulating } \\
\text { for all children. }\end{array}$ & $0,7 \%$ & $2,8 \%$ & $4,9 \%$ & $29,2 \%$ & $62,5 \%$ \\
\hline $\begin{array}{l}\text { We have a protocol } \\
\text { for dealing with the } \\
\text { perception of } \\
\text { prejudice. }\end{array}$ & $2,8 \%$ & $8,3 \%$ & $26,4 \%$ & $40,3 \%$ & $22,2 \%$ \\
\hline $\begin{array}{l}\text { We agree with the } \\
\text { management on the } \\
\text { organisation }\end{array}$ & $3,5 \%$ & $8,3 \%$ & $22,9 \%$ & $41,0 \%$ & $24,3 \%$ \\
\hline
\end{tabular}




\begin{tabular}{|l|l|l|l|l|l|}
\hline $\begin{array}{l}\text { training on the topic } \\
\text { of prejudice. }\end{array}$ & & & & \\
\hline $\begin{array}{l}\text { We had education on } \\
\text { the topic of } \\
\text { prejudices, their } \\
\text { recognition, } \\
\text { confrontation, } \\
\text { elimination, } \\
\text { awareness. }\end{array}$ & $4,2 \%$ & $9,7 \%$ & $18,8 \%$ & $38,2 \%$ & $29,2 \%$ \\
\hline
\end{tabular}

We also asked the respondents about the competencies for teaching the listed topics.

Table 4: Competences of educators

\begin{tabular}{|c|c|c|c|c|c|}
\hline & Rights & $\begin{array}{c}\text { Immigrants and } \\
\text { refugees }\end{array}$ & Discrimination & Acceptance & Multiculturalism \\
\hline No & $8,4 \%$ & $25,9 \%$ & $14 \%$ & $4,2 \%$ & $14 \%$ \\
\hline $\begin{array}{l}\text { I don't } \\
\text { know }\end{array}$ & $16,8 \%$ & $31,5 \%$ & $16,8 \%$ & $8,4 \%$ & $17,5 \%$ \\
\hline Yes & $74,8 \%$ & $42,7 \%$ & $69,2 \%$ & $87,4 \%$ & $68,5 \%$ \\
\hline
\end{tabular}

We included two open-ended questions in the survey. The first asked about the specific situation of working with immigrants, and the second about the perception and expression of prejudice in the organisation.

Examples of answers on the topic of immigrants:

- "In the morning round, together with the children, we learned a new word, which the child introduced to us, every day. We also invited an adult immigrant to introduce us to the language through fairy tales and their habits."

- "With the help of the immigrant's mother, we introduced other children to the country the immigrant came from. A wonderful collaboration that I have a fond memory of."

- "You always act for the good of the child, whether he is an immigrant or not. They are all the same, no matter where they come from."

Examples of answers to the topic of expressing and perceiving prejudice:

- "We also raise parents through children."

- "It's more about fear of the unknown."

- "In case of disagreement, children quickly start to scold each other with insults related to their origin."

\section{Findings}

Based on the data obtained in the empirical part of the research on prejudices between teachers and educators, we analysed the hypotheses. First, we considered closed and open questions of the survey questionnaire. Then, in analysing quantitative data, we used tests to determine the validity of hypotheses (T-test, Kolmogorov-Smirnov test). 
Our research showed that prejudices among educators in our survey are present. For example, the vulnerable groups covered by the survey have the most prejudice towards children with special needs.

Table 5: Answers regarding children with special needs

\begin{tabular}{|l|c|c|c|c|c|}
\hline & $\begin{array}{l}\text { I completely } \\
\text { disagree }\end{array}$ & I disagree & $\begin{array}{l}\text { I cannot } \\
\text { define } \\
\text { myself }\end{array}$ & I agree & $\begin{array}{l}\text { I } \\
\text { completely } \\
\text { agree }\end{array}$ \\
\hline $\begin{array}{l}\text { Children with special } \\
\text { needs should be } \\
\text { educated in schools } \\
\text { with a special } \\
\text { program. }\end{array}$ & $7,5 \%$ & $17,8 \%$ & $21,9 \%$ & $38,4 \%$ & $14,4 \%$ \\
\hline $\begin{array}{l}\text { A child with special } \\
\text { needs hinders the } \\
\text { work of other } \\
\text { children. }\end{array}$ & $10,3 \%$ & $34,9 \%$ & $22,6 \%$ & $28,8 \%$ & $3,4 \%$ \\
\hline $\begin{array}{l}\text { A child with special } \\
\text { needs has a positive } \\
\text { effect on developing } \\
\text { social skills in others } \\
\text { in the } \\
\text { classroom/playroom. }\end{array}$ & $2,1 \%$ & $7,5 \%$ & $19,2 \%$ & $53,4 \%$ & $17,8 \%$ \\
\hline
\end{tabular}

The data tell us about the influence of the employment institution and the education program on the presence of prejudice among educators. We have found out that there are differences in the presence of prejudices among educators concerning employment in a school or kindergarten. Kindergarten employees have more prejudices than those employed at the school.

Table 6: Answers regarding employment in kindergarten or school

\begin{tabular}{|l|l|r|r|}
\hline & Employment & Arithmetic mean & Standard deviation \\
\hline \multirow{2}{*}{ Prejudice } & Kindergarten & 44,0404 & 5,80098 \\
\cline { 2 - 4 } & School & 46,1064 & 5,73788 \\
\hline
\end{tabular}

According to the education program, there are also differences in the presence of prejudices according to the presence of prejudices among educators if they are employed in a regular or adjusted educational program. Employees in the regular education program have more prejudices.

Table 7: Prejudice regarding on program of employment

\begin{tabular}{|l|r|r|}
\hline Program & Arithmetic mean & Standard deviation \\
\hline Regular & 44,5649 & 5,82712 \\
\hline Special & 45,9333 & 6,02929 \\
\hline Together & 44,7055 & 5,84179 \\
\hline
\end{tabular}


The presence of prejudice among educators is not affected by their age or residence. We have found out that educators feel competent to teach various prejudice-related topics, such as human rights, equality, etc.

Based on the data obtained from the open-ended questions, we can say that professionals recognise prejudices and respond to them appropriately. They wrote down various examples of good practice, responses, experiences, prevention. They also listed the most common victims of prejudice, environments where prejudice occurs, and ways of expression.

Society is becoming more diverse, and values are changing. We are facing new challenges in all areas, which can make our work more difficult. Prejudices are part of our daily lives and part of all of us. These are often unconscious opinions. Prejudice is not harmful as long as our actions are not directed at violence. This is why it is essential to be aware of prejudices, think about them, reflect on them and try to alleviate them. This is not easy, so we need a supportive environment that allows us to do so.

In the empirical part, we explored the presence of prejudices among teachers and educators up to five vulnerable groups: immigrants, Roma, racial diversity, children with special needs, and the socio-economically disadvantaged. We have found that prejudices among professionals are present in my sample. Among the vulnerable groups covered by the survey, they have the most to children with special needs. The data tell us about the influence of the employment institution and the education program on the presence of prejudices among professionals. We have found differences in the presence of prejudice among professionals about employment in a school or kindergarten. Kindergarten employees have more prejudices than those employed at the school. There are also differences in the presence of prejudices according to the education program, which means that the presence of prejudices among professionals is affected if they are employed in a regular or adjusted education program. Employees in the regular education program have more prejudices. The presence of prejudice among professionals is not affected by their age or residence. We have found that professionals feel competent to teach a variety of prejudiced topics.

Based on the research findings, we would suggest the possibility of continuous education and training of professionals on this topic. It should be based mainly on concrete cases, awarenessraising, gaining experience, debate, etc. Ongoing awareness-raising, encouragement to perception, and appropriate response are needed.

It is crucial that educators raise awareness of prejudices, think about them, name them, and alleviate them. The entire education system must be included through additional training, practical experience, discussions, articles, professional literature, etc. Only this can provide adequate support and changes in this important area. Only together, we will make necessary changes that will positively impact the educators and personal growth of adults, children, and society.

\section{References}

Allport, G. W. (1979). The Nature of Prejudice. V I. Razpurker-Apfeld, in L. Shamoa-Nir (ur.), Psychology (str. 27-47). Cambridge: Perseus Books Cambridge.

Bešter, R. (2007). Integracija in model integracijske politike. V M. Komac (ur.), Priseljenci: študije o priseljevanju in vključevanju v slovensko družbo (str. 105-134). Ljubljana: Inštitut za narodnostna vprašanja.

Bluestein, J. (2001). Creating Emotionally Safe Schools. A Guide of Educators and Parents. Deerfield Beach Florida: Health Communications.

Brown, R. (2001). Prejudice. Oxford: Blackwell.

Ermenc, S. K. (2006). Slovenska šola z druge strani. Sodobna pedagogika, 57, 150-167.

Gogala, S. (1966). Obča metodika. Ljubljana: Državna založba Slovenije.

Grah, J., Kruh, J., Vovk - Ornik, N., in Rogič Ožek, S. (2019). Raznolikost v vrtcu in šoli. Priročnik za vzgojitelje, učitelje in druge strokovne delavce. 1. zvezek. Ljubljana: Zavod Republike Slovenije za šolstvo. 
https://zofijini.net/predsodki-stereotipi-diskriminacija-1-del/

Kesič Dimic, K. (2015). Vsi učenci so lahko uspešni. Ljubljana: Rokus Klett.

Košir, K. (2013). Socialni odnosi v šoli. Maribor: Subkulturni azil, zavod za umetniško produkcijo in založništvo.

Klemenčič, E., in Štremfel, U. (2011). Nacionalna in mednarodna perspektiva izobraževanja za državljanstvo v multikulturni družbi. Ljubljana: ZRC SAZU.

Krek, J., Globokar, R., Kalin, J., Kodelja, Z., Pribac, I., in Šimenc, M. (2011). Uvod. V M. Metljak (ur.). Bela knjiga o vzgoji in izobraževanju v Republiki Sloveniji (str. 11-62). Ljubljana: Zavod RS za šolstvo.

Kroflič, R. (2002). Šola - izkustveni prostor socialnega učenja in/ali moralne vzgoje. Sodobna pedagogika, 53(3), 42-51.

Kroflič, R. (2004). Učiteljeva zaveza vzgojnim ciljem javne šole. Sodobna pedagogika, 12(4), 39-55.

Kuhar, M. (2008). Mladi in stari stereotipi. Socialna pedagogika, 12(4), 39-55.

Mirovni inštitut. (2003). Prepoznavanje rasne diskriminacije in borba proti njej. Ljubljana: NUK.

MIZŠ. (2017). Vključevanje priseljencev $\mathrm{v}$ sistem vzgoje in izobraževanja. Pridobljeno s http://www.mizs.gov.si/si/vkljucevanje_priseljecev_v_sistem_vzgoje_in_izobrazevanja/

Osmanović, S. (2019). Kompetence strokovnih delavcev za delo v medkulturnem okolju (magistrska naloga). Mednarodna fakulteta za družbene in poslovne študije, Celje.

Palomares, S. (2001). Spodbujanje strpnosti in spoštovanja drugačnosti. Ljubljana: Inštitut za psihologijo osebnosti.

PREDIS. (2013). Preprečevanje predčasnega opuščanja šolanja v poklicnem izobraževanju s strategijami vključevanja za priseljence in Rome. Pridobljeno s https://www.predis.eu/15433.html

Trunk Širca, N. in Novak Trunk, A. (2017). Učenci priseljenci in medkulturne kompetence učiteljev. V M. Kezunović Krašek (ur.), Znanje za moje sanje. Pot k etični vzgoji - dobre prakse v izobraževanju beguncev in migrantov (str. 126-130). Ljubljana: Pisarna poslanke Evropskega parlamenta Tanje Fajon.

Ule, M. (2004). Socialna psihologija. Ljubljana: FDV.

Vižintin, M. A. (2017). Medkulturna vzgoja in izobraževanje: vključevanje otrok priseljencev. Ljubljana: Založba ZRC SAZU.

Židan, A. (2007). Za kakovostnejša družboslovna znanja: didaktični in znanstveni prispevki. Ljubljana: Fakulteta za družbene vede. 